\title{
EFFECT OF FOLIAR SPRAY WITH SOME SILICON SOURCES AND PACLOBUTRAZOL ON GROWTH, YIELD AND FRUIT QUALITY OF SWEET PEPPER (CAPSICUM ANNUUM L.) PLANTS UNDER HIGH TEMPERATURE CONDITIONS
}

\author{
ABDEL-AZIZ, M. A. and R. H. M. GEETH \\ Self-Pollination Veget. Dept.; Hort. Res. Inst.; ARC, Giza, Egypt. \\ Corresponding author: E-mail:drmedhataziz@yahoo.com
}

(Manuscript received 11 January 2018)

\begin{abstract}
$\mathrm{T}$ his study was carried out during the two late summer seasons of 2016 and 2017 at Sids Horticulture Research Station, Beni Sueif Governorate, Agriculture Research Center, Egypt. The objectives of this study were to investigate the effect of foliar spraying with five silicon sources i.e. sodium meta silicate, potassium silicate, kaolin clay particle film, fine crushed of the raw silicon and sunless, in addition paclobutrazol compound at two rates as well as the control treatment (spraying with tap water) under the two late summer seasons condition on the vegetative growth parameters, fruit set $\%$, average fruit weight, yield and its components, fruit quality and some chemical contents in sweet pepper leaves. The experimental design was a randomized complete block containing eight treatments with three replications. Pepper seedlings of Super Star F1 hybrid were transplanted in the $1^{\text {st }}$ week of May during the two late summer seasons, respectively.The results showed that, the most estimated parameters were significantly affected with silicon sources and paclobutrazol treatments as foliar applications; the superiority effect of the treatments was recorded by using kaolin (Aluminum silicate) followed by potassium silicate and paclobutrazol at a rate of $50 \mathrm{mg} / \mathrm{L}$ as well as sunless respectively, which led to obtain the highest significant increase in all the previous studied traits under high temperature stress condition. The remarkable of treated sweet pepper plants with kaolin material leading to increasing in the total yield and decreasing un-marketable yield (ton/ fed.) based on decreasing the injuries of sunburn on pepper fruits as a disorder disease compared with the control treatment. The severity of this disease which increase under the conditions of the late summer season characterize with the high temperature stress led to sun scale injury at this time of the season, because of the increases of ultraviolet and infrared radiation which prevailing during this critical period of the late summer season, causes serious physiological diseases sun scale or sunburn on pepper fruits, for that the study recommend spraying pepper plants grown under high temperature stress with any one of the previous mentioned silicon sources, particularly using kaolin compound which applied after 30 days from transplanting and repeated at 15 day intervals at four times to obtain the highest yield, best quality and highest net return, because it is the preferable are comparing to the other treatments. Keywords: Sweet pepper, High temperature stress, Kaolin, Silicon and Paclobutrazol
\end{abstract}


578 EFFECT OF FOLIAR SPRAY WITH SOME SILICON SOURCES AND PACLOBUTRAZOL ON GROWTH, YIELD AND FRUIT QUALITY OF SWEET PEPPER (CAPSICUM ANNUUM L.) PLANTS UNDER HIGH TEMPERATURE CONDITIONS

\section{INTRODUCTION}

It is known that, fresh sweet pepper fruit (Capsicum annum $\mathrm{L}$ ) is the most popular and economically important vegetable crop in Egypt and worldwide due to its high quantities of ascorbic acid and some important elements as well as their attractive red color at maturity stage and this is due to several carotenoids pigments that include $\beta$ carotene with pro-vitamin A activity and oxygenated carotenoids such as capsantine, capsorubin, and cryptocapsin, which are exclusive to these fruits and have proven to be effective at scavenging free radicals, which provide beneficial effects on human health which this due to their antioxidant properties, led to a positive protection and play an importance role against the oxidative damage to cells and thus prevent the development of common diseases such as cancer, cardiovascular diseases, cataracts and diabetes (Blanco-Ríos et al., 2013).

Cultivation of sweet pepper plants in the late stages of summer season from May to the first of September during this time, the temperature increased strongly, when the extreme temperature becomes more than $40.0,20.2,39.7$ and $20.0^{\circ} \mathrm{C}$ at day and night as recorded in July, $41.5,19.1,41.0$ and $21.0^{\circ} \mathrm{C}$ at day and night as recorded in August (Table 1 ) in the $1^{\text {st }}$ and $2^{\text {nd }}$ late summer seasons, respectively. The optimum temperature for pepper cultivation is 28 to $20^{\circ} \mathrm{C}$ at day and night; temperature strongly influenced positively on the development of flower and pepper fruits.

Reducing heat stress on sweet pepper plants is an important factor to ensure the optimum growth, yield and quality. In this respect, high temperature stress is defined as the rise in temperature beyond a critical threshold for a period of time sufficient to cause serious injuries or damage the plant growth and reducing its development, its including number of biochemical reactions, i.e. decreased shoot dry weight, relative growth rate, scorching of leaves and twigs, sunburns on leaves, branches, stems, fruit, leaf senescence, abscission, shoot and root growth inhibition, decrease in photosynthesis, bad effect on the size of fruit, fruit discoloration and perhaps damage. High temperature frequently occurs after anthesis of pepper and strongly impacts the reproduction and yield. High temperature also, tendency towards reduced cell size, closure of stomata with a larger stomatal opening area, thinner leaves and loose arrangement of mesophyll cells showed that elevated temperatures during flower development can markedly reduce the fruit set and this case attributed to low pollen viability (Tran and Murakami, 2015).

As regard to the effect of silicon treatments, Ahmed (2017) generalized that kaolin (aluminum silicate) is a reflective antitranspirant material, when sprayed it on 
the plants induce covering the leaves and fruits with thin films of nanoparticles as a white color and increasing their reflectance properties of light. The kaolin particle film reflects photo synthetically active, ultraviolet and infrared radiations thus reduce high temperatures stress of treated the plant organs i.e. leaves, fruits and mitigating environmental stresses, increasing vegetative growth, yield, its components and fruit quality. Thus the kaolin has been used to prevent fruit sunburn damage as well as suppress diseases, protect crops from insect pests and save water by reducing transpiration of tomato plants.

Concerning to the role of paclobutrazol it belongs to triazolic group of fungicides which have as plant growth regulators properties. The application of paclobutrazol has no harmful effects on human health and it enhances the production and increasing yield of several crops. It can induce several growth regulation properties such as morphological and biochemical changes, like reduction in shoot elongation; stimulation of rooting; changes in stem length and weights of seedlings; inhibition of gibberellins synthesis; increase in chlorophyll and carotenoid content; improvement of the carbohydrate metabolism, ascorbic acid, increase in cytokinin synthesis; improvement of photosynthetic activity and water balance; increase in the proline content, soluble sugars and stimulation of antioxidative enzyme systems. Paclobutrazol has been found to protect several plants from various environmental stresses, including drought, heat and ultraviolet radiations (280-320 NM) reduction in the rate of transpiration (due to reduction in leaf area), increased alleviating reduction in water potential, increased relative water content, less water uses and induce increases in the activity of antioxidant enzymes. Paclobutrazol induced stress tolerance due to the protection of plants from apparently unrelated stresses by triazole, as well as mediated by reduction in free radical damage and increase in the antioxidant potential and an efficient free-radical scavenging system that enables them to detoxify active oxygen, the previous information was mentioned by Unyayar and Ozlem (2005).

The purpose of this investigation was to study the effect of spraying the plants with some silicon sources or paclobutrazol treatments to protect pepper plant and its fruit from heat stress and reflect of that on invigoration the growth, enhancing yield productivity as well as, fruit quality either physical or chemical properties of leaves and fruits.

\section{MATERIALS AND METHODS}

This study was performed during the two late summer seasons of 2016 and 2017 at Sids Horticulture Research Station, Beni Sueif Governorate, Agriculture Research 
580 EFFECT OF FOLIAR SPRAY WITH SOME SILICON SOURCES AND PACLOBUTRAZOL ON GROWTH, YIELD AND FRUIT QUALITY OF SWEET PEPPER (CAPSICUM ANNUUM L.) PLANTS UNDER HIGH TEMPERATURE CONDITIONS

Center, Egypt. The targets of this investigation were to investigate the effect of using five different silicon sources and two concentrations of paclobutrazol compound beside the control to increase the ability of sweet pepper plants on growth, productivity, fruit quality and some chemical composition contents either in the leaves or in the fruits under the condition of high temperature stress.

The meteorological data for the experimental area obtained from Central Laboratory for Agricultural Climate (CLAC), Agricultural Research Center (ARC), Ministry of Agricultural and Land Reclamation. The values were recorded during the two growing late summer seasons at Sids, Beni Sueif Governorate as shown in Table 1.

Table 1. Meteorological data at Sids, Beni Sueif Governorate region during the two late summer seasons of 2016 and 2017

\begin{tabular}{|c|c|c|c|c|}
\hline \multirow{2}{*}{ Months } & \multicolumn{4}{|c|}{ Temperature ${ }^{\circ} \mathrm{C}$} \\
\cline { 2 - 5 } & \multicolumn{2}{|c|}{2016} & \multicolumn{2}{c|}{2017} \\
\cline { 2 - 5 } & Maximum & Minimum & Maximum & Minimum \\
\hline May & 39.0 & 14.0 & 39.6 & 15.0 \\
\hline June & 39.5 & 19.1 & 39.0 & 19.5 \\
\hline July & 40.0 & 20.2 & 39.7 & 20.0 \\
\hline August & 41.5 & 19.1 & 41.0 & 21.0 \\
\hline September & 38.7 & 16.5 & 38.5 & 16.2 \\
\hline
\end{tabular}

Sweet pepper seedlings were cultivated in clay-loam soil, the soil type of the experimental field was alluvial clay. Soil samples were taken randomly of each season, before planting at the depth of $0-30 \mathrm{~cm}$. Table 2 . shows some physical and chemical properties of the experimental soil before planting according to the methods described by Jackson (1973).

The experimental design was a randomized complete block containing eight treatments with three replications. The treatments included foliar spraying with some silicon sources, two rate of paclobutrazol, the names and contents beside the control are shown in Table 3 beside the control. All treatments were used as a fine mist foliar application till run-off with care to cover all plant organs. After 40 days from seed sowing in the nursery uniform using Super Star F1 hybrid pepper, seedlings were transplanted by hand at the fourth true leaf stage in the open field at $30 \mathrm{~cm}$ apart on one side of the ridge at the $1^{\text {st }}$ week of May during 2016 and 2017 seasons, respectively. The experimental unit consisted of $11.2 \mathrm{~m}^{2}$ which included 4 ridges each of $0.7 \mathrm{~m}$ width and $4 \mathrm{~m}$ length. The different treatments were applied at four times, the $1^{\text {st }}$ foliar spraying started after 30 days from transplanting the seedlings and repeated at 15 day intervals during the growth period of the two late summer seasons, respectively. 
Table 2. Physical and chemical properties of the experimental soil during the two late summer seasons of 2016 and 2017

\begin{tabular}{|c|c|c|}
\hline Components & 2016 & 2017 \\
\hline Soil Type & \multicolumn{2}{|c|}{ alluvial clay } \\
\hline Organic Matter \% & 1.90 & 2.02 \\
\hline Clay \% & 42.66 & 67.76 \\
\hline Silt \% & 24.37 & 21.23 \\
\hline Fine Sand \% & 8.49 & 10.20 \\
\hline Coarse Sand \% & 72.0 & 0.81 \\
\hline PH & 7.60 & 7.40 \\
\hline E C (mmhos / cm) & 0.61 & 0.76 \\
\hline CaCO3 \% & 2.70 & 2.90 \\
\hline Available N (ppm) & 23.00 & 15.5 \\
\hline Available P (ppm) & 7.60 & 5.80 \\
\hline Available K (ppm) & 388.30 & 336.10 \\
\hline
\end{tabular}

Guard rows were set between the experimental units to avoid drifting to the adjacent plots. All recommended agricultural practices for sweet pepper plants plantation were followed according to the recommendation of the Egyptian Ministry of Agriculture and Land Reclamation.

\section{Recorded data:}

\section{I- Vegetative growth parameter measurements:}

Five plants were taken randomly from the inner two ridges for each plot after ten days from the last spray (after 85 days from transplanting) to measure the following vegetative growth parameters i.e. plant height $(\mathrm{cm})$, number of branches/ plant, fresh and dry weights of leaves/ plant $(\mathrm{g})$.

\section{II- Yield and its components (ton/ fed.):}

II-1- Fruit set \%: Estimated with an average of twenty flowers at five plants/ plot after 85 days from transplanting in the two late summer seasons using the following equation: Fruit set $\%=$ No. of fruits $/$ Total No. of twenty flowers $\times 100$

II-2- Fruit weight: Includes average of the representative sample of ten sweet pepper fruits taken from the first three pickings.

II-3-Early yield: Includes weight of the first three pickings.

II-4-Marketable yield: At edible stage which, includes all the fruits reached to the full size which are characterized to be shiny green, intact, straight, with a fresh appearance and without any pest defects, diseases and non-deformed.

II-5-Un-marketable yield: Includes the sunburn (necrosis on sweet pepper fruits), defective, malformed, pale colored, broken, overgrown, short and small fruits, symptoms of pest and disease damage were considered un-marketable.

II-6-Total yield: Includes all the numbers of harvested fruits collecting from the outer two ridges along the two late summer seasons, respectively. 
582 EFFECT OF FOLIAR SPRAY WITH SOME SILICON SOURCES AND PACLOBUTRAZOL ON GROWTH, YIELD AND FRUIT QUALITY OF SWEET PEPPER (CAPSICUM ANNUUM L.) PLANTS UNDER HIGH TEMPERATURE CONDITIONS

Table 3. The compounds names and its composition, sources and concentration/ L which it's used as a foliar spray during the two growth period under the condition of the two late summer seasons of 2016 and 2017

\begin{tabular}{|c|c|c|c|}
\hline Compounds & Composition & Sources & Concentration/ L \\
\hline $\begin{array}{l}\text { Sodium meta } \\
\text { silicate }^{\circledR}\end{array}$ & $\begin{array}{c}\left(\mathrm{Na}_{2} \mathrm{SiO}_{3} 5 \mathrm{H}_{2} \mathrm{O}\right) \text { used as } \\
\text { a powder form }\end{array}$ & $\begin{array}{c}\text { Techno Gene establishment } \\
\text { for importation and } \\
\text { exportation Co., Ltd. Giza - } \\
\text { Egypt }\end{array}$ & $1 \mathrm{~g} / \mathrm{L}$ \\
\hline $\begin{array}{l}\text { Potassium } \\
\text { silicate }^{\circledR}\end{array}$ & $\begin{array}{l}\text { Potassium silicate }\left(\mathrm{K}_{2} \mathrm{SiO}_{3}\right. \\
\text { - contains } 22.5 \% \mathrm{SiO}_{2} \\
\left.\text { and } 10.25 \% \mathrm{~K}_{2} \mathrm{O}\right) \text { used } \\
\text { as a powder form }\end{array}$ & $\begin{array}{l}\text { Importer: El-Goumhouria } \\
\text { Co. For trading medicines, } \\
\text { chemicals and medical } \\
\text { appliances, Cairo - Egypt. }\end{array}$ & $1 \mathrm{~g} / \mathrm{L}$ \\
\hline Kaolin ${ }^{\circledR}$ & $\begin{array}{c}\text { Kaolin clay particle film } \\
\text { (Aluminum silicate - } \\
\mathrm{Al}_{2} \mathrm{O}_{7} \mathrm{Si}_{2} \text { ). Concentration of } \\
\mathrm{Al} \text { at } 0.7 \% \text { and } \mathrm{Si} \text { at } 48.8 \\
\mathrm{mg} / \mathrm{kg} \text {, used as a powder } \\
\text { form }\end{array}$ & $\begin{array}{l}\text { Manufactured by Green } \\
\text { Way Naturals Co., Ltd. } \\
\text { Ismailia - Egypt. }\end{array}$ & $20 \mathrm{~g} / \mathrm{L}$ \\
\hline Raw silicon & $\begin{array}{l}\text { Pure of fine crushed of } \\
\text { the raw Silicon (Quartz - } \\
\mathrm{SiO}_{2} \text { ) used as a powder } \\
\text { form }\end{array}$ & $\begin{array}{l}\text { Quartz }-\mathrm{SiO}_{2} \text { washed with } \\
\text { a dilute hydrochloric acid at } \\
\text { the concentration of } 5 \% \text {, } \\
\text { followed by washing with } \\
\text { distillation water then dried, } \\
\text { crushed and sifted. }\end{array}$ & $1 \mathrm{~g} / \mathrm{L}$ \\
\hline Sunless ${ }^{\circledR}$ & $\begin{array}{l}\text { Sunless (contains } \\
\text { potassium thio silicate at } \\
15 \% \text {, magnesium thio } \\
\text { silicate at } 15 \% \text { and } \\
\text { ammonium sulfate at } 3 \\
\% \text { ), used as a liquid form }\end{array}$ & $\begin{array}{l}\text { Union chemicals- } \\
\text { Chemical fertilizer producer } \\
\text { Co., Ltd. - } \\
\text { Egypt }\end{array}$ & $2 \mathrm{Cm}^{3} / \mathrm{L}$ \\
\hline Paclobutrazol ${ }^{\circledR}$ & $\begin{array}{c}\text { Paclobutrazol }\left(\mathrm{PP}_{333}\right) \\
{[(2 \mathrm{RS}, 3 \mathrm{RS})-1-(4-} \\
\text { chlorophenyl) }-4,4- \\
\text { dimethyl-2-(1H-1,2,4 } \\
\text { triazole-1- yl) pentan-3-ol] } \\
\mathrm{C}_{15} \mathrm{H}_{20} \mathrm{CIN} \mathrm{N}_{3} \mathrm{O}-\mathrm{F} \text { W } 293.79, \\
\text { used as a powder form }\end{array}$ & $\begin{array}{l}\text { The importer company is } \\
\text { Techno Gene establishment } \\
\text { for importation and } \\
\text { exportation Co., Ltd. Giza - } \\
\text { Egypt }\end{array}$ & $\begin{array}{c}50 \text { or } 100 \\
\mathrm{mg} / \mathrm{L}\end{array}$ \\
\hline Control & \multicolumn{3}{|c|}{ Spraying with tap water } \\
\hline
\end{tabular}

\section{III-Fruit quality characteristics of sweet pepper fruit:}

A representative sample of ten sweet pepper fruits from each experimental plot of the outer two ridges at the marketable green ripe stage was taken from the $3^{\text {rd }}$ picking to determine the following data i.e. average fruit length $(\mathrm{cm})$, fruit diameter $(\mathrm{cm})$, fruit dry weight (\%), total soluble solids percentage (T. S. S. \%) determined by using a hand refractrometer. Total acidity (\%) and ascorbic acid (Vitamin C), content 
in pepper fruit tissues ( $\mathrm{mg} / 100 \mathrm{~g}$ fresh weight) according to the method mentioned in the (A.O.A.C., 2005).

\section{IV- Chemical composition determinations of sweet pepper leaves:}

\section{IV-1- Minerals contents:}

Fresh samples of sweet pepper leaves and fruits were dried in an electric forcedair oven at $70^{\circ} \mathrm{C}$ to constant weight then fractionated and sifting. The fine powder (at $0.2 \mathrm{~g}$ ) of each dry sample was digested in a mixture of sulphuric and perchloric acids, as wet digestion according to Piper (1947). Total nitrogen, phosphorus and potassium contents (\%) were determine according to Bremner and Mulvaney (1982), Olsen and Sommers (1982) and Horneck and Hanson (1998), respectively.

IV-2- Photosynthetic pigments: Total chlorophyll content $(\mathrm{mg} / 100 \mathrm{~g}$ fresh weight) was determined in the fresh leaves after ten days from the last spray, according to the method described by Nagata and Yamashita (1992).

IV-3-Total sugars contents $(\mathrm{mg} / \mathrm{g})$ in dry leaves and $(\%)$ in dry fruit were determined according to Dubois et al. (1975).

IV-4-Free proline content $(\mathrm{mg} / \mathrm{g})$ in dry leaves was determined according to Troll and Lindsley (1955).

\section{V-Economic evaluation:}

Economic evaluation was performed based on, calculated with the respect market price multiplying mean of the two seasons on total green sweet pepper fruit yield (ton/ fed.) $\times$ Average selling price of one ton of total fruit yield - (costs of the materials + worker cost/ one fed.) $=$ Total income for each treatment with/fed. Net return $=$ Return of the treatment - Return of the control with Egyptian Pound /fed.

\section{VI-Statistical analysis:}

All obtained data of the present study were subjected to the analysis of variance techniques according to the design used by the MSTATC computer software program variance and the mean of treatments were compared according to the Least Significant Differences ( $L S D$ ) test at the 0.05 probability level, the method described by Bricker (1991).

\section{RESULTS AND DISCUSSION}

\section{I- Vegetative growth parameters:}

Regarding to the effect of foliar spraying with various some silicon sources and paclobutrazol treatments on sweet pepper plants subjected to heat stress condition on the vegetative growth parameters i.e. plant height, number of branches, fresh and dry weights of leaves/ plant, the data registered in Table (4) showed clearly that, foliar spraying of sweet pepper plants with all used treatments significantly increased plant height, number of branches, fresh and dry weights of leaves except spraying with paclobutrazol at the highest rate i.e. $100 \mathrm{mg} / \mathrm{L}$ which gave non-significant value on 
584 EFFECT OF FOLIAR SPRAY WITH SOME SILICON SOURCES AND PACLOBUTRAZOL ON GROWTH, YIELD AND FRUIT QUALITY OF SWEET PEPPER (CAPSICUM ANNUUM L.) PLANTS UNDER HIGH TEMPERATURE CONDITIONS

the vegetative growth parameters except for the lateral branches in both seasons when

Table 4. Effect of foliar spray with some silicon sources and paclobutrazol treatments on vegetative growth parameters of sweet pepper plants during the two late summer seasons of 2016 and 2017

\begin{tabular}{|c|c|c|c|c|c|c|c|c|}
\hline \multirow[t]{2}{*}{$\begin{array}{l}\text { Foliar spray } \\
\text { treatments }\end{array}$} & \multicolumn{2}{|c|}{ Plant height $(\mathrm{cm})$} & \multicolumn{2}{|c|}{$\begin{array}{c}\text { Number of } \\
\text { branches/ plant }\end{array}$} & \multicolumn{2}{|c|}{$\begin{array}{c}\text { Fresh weight } \\
\text { of leaves }(\mathrm{g}) / \text { plant }\end{array}$} & \multicolumn{2}{|c|}{$\begin{array}{l}\text { Dry weight } \\
\text { of leaves }(g) /\end{array}$} \\
\hline & 2016 & 2017 & 2016 & 2017 & 2016 & 2017 & 2016 & 2017 \\
\hline $\begin{array}{c}\text { Sodium meta } \\
\text { silicate }^{\circledR} \text { at } 1 \mathrm{~g} / \mathrm{L}\end{array}$ & 75.39 & 76.43 & 4.75 & 4.56 & 188.40 & 184.70 & 26.90 & 26.33 \\
\hline $\begin{array}{c}\text { Potassium silicate }^{\circledR} \\
\text { at } 1 \mathrm{~g} / \mathrm{L}\end{array}$ & 79.44 & 79.69 & 5.62 & 5.45 & 205.70 & 205.97 & 29.33 & 29.40 \\
\hline Kaolin $^{\circledR}$ at $20 \mathrm{~g} / \mathrm{L}$ & 83.48 & 83.82 & 5.82 & 5.78 & 218.17 & 218.87 & 31.13 & 31.37 \\
\hline Raw silicon at $1 \mathrm{~g} / \mathrm{L}$ & 69.43 & 69.84 & 4.52 & 4.32 & 180.47 & 174.60 & 25.77 & 24.87 \\
\hline Sunless ${ }^{\circledR}$ at $2 \mathrm{~cm}^{3} / \mathrm{L}$ & 77.27 & 78.98 & 5.53 & 5.34 & 194.43 & 195.67 & 27.73 & 27.90 \\
\hline $\begin{array}{c}\text { Paclobutrazol }^{\circledR} \text { at } 50 \\
\mathrm{mg} / \mathrm{L}\end{array}$ & 65.84 & 65.32 & 5.34 & 5.17 & 172.53 & 162.40 & 24.60 & 23.17 \\
\hline $\begin{array}{c}\text { Paclobutrazol }^{\circledR} \text { at } \\
100 \mathrm{mg} / \mathrm{L}\end{array}$ & 61.94 & 60.77 & 5.06 & 4.96 & 163.20 & 152.10 & 23.23 & 21.70 \\
\hline Control (Tap water) & 58.07 & 57.39 & 3.66 & 3.71 & 152.60 & 143.87 & 21.77 & 20.53 \\
\hline L S D at $5 \%$ & 5.17 & 4.29 & 33.0 & 0.28 & 16.28 & 14.36 & 2.32 & 2.03 \\
\hline
\end{tabular}

compared with the control treatment. The most effective treatments producing the highest growth parameters were i.e. kaolin at $20 \mathrm{~g} / \mathrm{L}$ followed with potassium silicate at $1 \mathrm{~g} / \mathrm{L}$ and sunless at $2 \mathrm{~cm}^{3} / \mathrm{L}$ as well as sodium meta silicate at $1 \mathrm{~g} / \mathrm{L}$. respectively.

These positive results on vegetative growth with foliar spraying by different silicon treatments on sweet pepper plant may be due to that, silicon deposition in the cell wall of xylem vessels prevents compression of the vessels under the condition of high transpiration caused by heat stress. The silicon prescience in cellulose membrane of epidermal tissue protects the plants against excessive loss of water by transpiration.

Accumulation of silicon will produce a thick silicate layer on the leaf surface which effectively reduces cuticular transpiration up to $30 \%$ as well as a thick layer of silica gel is associated with cellulose in the epidermal cell wall but less silica gel will allow water to escape at an accelerated rate. Silicon is considering as an antitranspirant which ascribed to the important role of blocking stomata without causing any inferior effects on photosynthesis, which retards normal moisture loss without interfering with plant growth or normal respiration.

In addition, a reflective kaolin spray was found to decrease the leaf temperature by increasing leaf reflectance and this reduce transpiration rate which enhance the efficiency of photosynthesis in many plant species grown at high solar radiation levels leading to promote the vegetative growth. 
Corresponding, potassium silicate which contains $10.25 \% \mathrm{~K}_{2} \mathrm{O}$, potassium can enhance the total dry mass accumulation of sweet pepper plants under drought stress which accompanied with high temperature (under the condition of this investigation); this finding might be attributed to stomatal regulation by potassium and corresponding higher rates of photosynthesis as well as potassium is considered to be the key to promote the growth of meristematic tissue as well as increased level of nitrogen also promotes the vegetative growth. Furthermore, potassium is also essential for the translocation of photo assimilates in root growth and increase the root surface and subsequence increased root water as well as minerals uptake.

Concerning to the role of the raw silicon, a similar trend was reported by AbdelAziz (2007) who pointed out that foliar application of the raw silicon and sodium met silicate at a rate of $1 \mathrm{~g} / \mathrm{L}$ of each other occurred an increasing in the vegetative growth of tomato plants in the early and late summer seasons. Kamal (2013) mentioned that spraying kaolin at a rate of $4 \%$ and potassium silicate at a rate of 1.5 $\mathrm{kg} /$ fed. obtained an increase in vegetative growth characteristics of sweet pepper plants. Ahmed (2017) concluded that kaolin processing technology plays a key role in reducing plant transpiration, the treated plants became more cooler than the control plants by $2-3^{\circ} \mathrm{C}$ as well as its reflect the harmful of solar radiation with reflection i.e. infrared and ultraviolet radiation resulted an increasing in the plant growth. In addition, kaolin foliar application was reported to improve $\mathrm{CO}_{2}$ assimilation under high temperature stress and this is enhancing photosynthesis.

Regarding to role of spraying paclobutrazol treatments under heat stress condition, the obtained results are consistent with those observed by Yadava (2012) who assumed that foliar application of paclobutrazol at a rate of $50 \mathrm{ppm} / \mathrm{L}$ led to significant increases on growth rate and cumulative growth of Cape gooseberry plant.

\section{II- Yield and its components:}

Concerning to the effect of foliar application with some silicon sources and paclobutrazol treatments on fruit set \%, fruit weight, yield and its components of sweet pepper fruit are presented in Table 5. It is evident that all foliar application treatments specially spraying pepper plants with kaolin followed with potassium silicate as well as paclobutrazol at the low rate and sunless led to significant increases in fruit set \%, early, marketable total yields and decreasing un-marketable yield as compared with the rest treatments and control with the exception of spraying the raw silicon at the $1^{\text {st }}$ season only on total yield and paclobutrazol treatment at the highest rate i.e. $100 \mathrm{mg} / \mathrm{L}$ on marketable and total yield in the two late summer seasons, respectively. The total yield (ton/ fed.) value under kaolin treatment application occurred higher value by 51.05 and $47.84 \%$ and decreasing un-marketable yield value lower by 34.5 and $41.01 \%$ in the $1^{\text {st }}$ and $2^{\text {nd }}$ at late summer seasons, respectively as comparing with the untreated plants. These results are considered 
586 EFFECT OF FOLIAR SPRAY WITH SOME SILICON SOURCES AND PACLOBUTRAZOL ON GROWTH, YIELD AND FRUIT QUALITY OF SWEET PEPPER (CAPSICUM ANNUUM L.) PLANTS UNDER HIGH TEMPERATURE CONDITIONS

highly superior for producing pepper fruit yield under this time of summer season under high temperature stress.

These remarkable results of treated sweet pepper plants with some silicon sources in the previous aspects could be explained that silicon deposited in the cell walls forms a protective layer reducing transpiration through the outer cells under the conditions of high transpiration caused by drought or heat stress contributing in the enhancement of photosynthesis and dry matter content. Furthermore, silicon in plants can increase the thickness and hardness of fruit because of the accumulation of silicon on the epidermal tissues, silicon has been found more tolerant against pests which it is considered to be due either to accumulation of absorbed silicon in the epidermal tissue or expression of pathogenesis induced host defense responses. By this means, a double cuticular layer protects and mechanically strengthens plants and fruit leading to healthy sweet pepper plants as well as vigour vegetative growth and subsequence leading to increasing fruit set \%, fruit weight, yield and its components.

Table 5. Effect of foliar spray with some silicon sources and paclobutrazol treatments on fruit set, fruit weight, yield and its components (ton/ fed.) of sweet pepper plants during the two late summer seasons of 2016 and 2017

\begin{tabular}{|c|c|c|c|c|c|c|}
\hline Foliar spray treatments & $\begin{array}{l}\text { Fruit set } \\
(\%)\end{array}$ & $\begin{array}{c}\text { Fruit } \\
\text { weight (g) }\end{array}$ & $\begin{array}{l}\text { Early } \\
\text { yield } \\
\text { (Ton/ } \\
\text { fod) } \\
\end{array}$ & $\begin{array}{c}\text { Marketable } \\
\text { yield } \\
\text { (Ton/ fed.) }\end{array}$ & $\begin{array}{c}\text { Un- } \\
\text { marketable } \\
\text { yield } \\
(\text { Ton / fod } 1\end{array}$ & $\begin{array}{l}\text { Total yield } \\
\text { (Ton/ } \\
\text { fed.) }\end{array}$ \\
\hline & \multicolumn{6}{|c|}{2016} \\
\hline $\begin{array}{c}\text { Sodium meta silicate }^{\circledR} \\
1 \mathrm{~g} / \mathrm{L}\end{array}$ & 74.68 & 55.653 & 3.787 & 9.016 & 0.575 & 9.591 \\
\hline Potassium silicate ${ }^{\circledR}$ at $1 \mathrm{~g} / \mathrm{L}$ & 80.40 & 60.227 & 4.270 & 10.660 & 0.560 & 11.220 \\
\hline $\mathrm{Kaolin}^{\circledR}$ at $20 \mathrm{~g} / \mathrm{L}$ & 84.18 & 61.533 & 4.400 & 11.280 & 0.511 & 11.791 \\
\hline Raw silicon at $1 \mathrm{~g} / \mathrm{L}$ & 69.45 & 52.557 & 3.287 & 8.080 & 0.515 & 8.595 \\
\hline Sunless ${ }^{\circledR}$ at $2 \mathrm{~cm}^{3} / \mathrm{L}$ & 77.33 & 57.963 & 4.033 & 9.609 & 0.505 & 10.114 \\
\hline Paclobutrazol ${ }^{\circledR}$ at $50 \mathrm{mg} / \mathrm{L}$ & 78.66 & 59.523 & 4.124 & 9.777 & 0.514 & 10.291 \\
\hline Paclobutrazol ${ }^{\circledR}$ at $100 \mathrm{mg} / \mathrm{L}$ & 72.15 & 50.213 & 3.560 & 7.691 & 0.553 & 8.244 \\
\hline Control (Tap water) & 65.86 & 44.496 & 2.463 & 7.026 & 0.780 & 7.806 \\
\hline LS D at $5 \%$ & 59.3 & 3.517 & 0.367 & 0.786 & 0.090 & 0.831 \\
\hline Foliar spray treatments & \multicolumn{6}{|c|}{2017} \\
\hline $\begin{array}{c}\text { Sodium meta silicate }^{\circledR} \\
\text { at } 1 \mathrm{~g} / \mathrm{L} \\
\end{array}$ & 74.64 & 52.703 & 3.747 & 8.840 & 0.564 & 9.404 \\
\hline Potassium silicate ${ }^{\circledR}$ at $1 \mathrm{~g} / \mathrm{L}$ & 80.86 & 61.290 & 4.320 & 10.141 & 0.533 & 10.674 \\
\hline Kaolin $^{\circledR}$ at $20 \mathrm{~g} / \mathrm{L}$ & 83.75 & 63.787 & 4.471 & 10.729 & 0.446 & 11.175 \\
\hline Raw silicon at $1 \mathrm{~g} / \mathrm{L}$ & 69.89 & 50.400 & 3.238 & 7.992 & 0.508 & 8.500 \\
\hline Sunless ${ }^{\circledR}$ at $2 \mathrm{~cm}^{3} / \mathrm{L}$ & 76.64 & 56.590 & 3.950 & 9.614 & 0.505 & 10.119 \\
\hline Paclobutrazol $^{\circledR}$ at $50 \mathrm{mg} / \mathrm{L}$ & 79.28 & 59.130 & 4.145 & 9.870 & 0.519 & 10.389 \\
\hline Paclobutrazol ${ }^{\circledR}$ at $100 \mathrm{mg} / \mathrm{L}$ & 71.06 & 48.507 & 3.468 & 7.653 & 0.576 & 8.229 \\
\hline Control (Tap water) & 64.97 & 43.187 & 2.577 & 6.803 & 0.756 & 7.559 \\
\hline L S D at $5 \%$ & 3.96 & 3.329 & 0.323 & 0.840 & 0.120 & 0.911 \\
\hline
\end{tabular}

As known, the high solar radiation and temperatures (under the condition of this investigation) cause high rates of plant water loss and plants regularly show 
symptoms of burn or withering in leaves or fruits, in this respect, kaolin processing technology plays an important role in the ability of the final product to reflect on reducing harmful solar radiation stress in the crop by lowering temperatures inside the plants or around the vegetative growth as a result of spraying the plant organs which protect the vegetative growth and the fruits from damaging by ultraviolet and infrared radiation while photosynthesis still occurring. Sunburn reduces the commercial value of plant products and also makes them vulnerable to decay by secondary infection by microorganisms. Silicon and kaolin are more effective at preventing pepper fruits from insects and sunburn; this may be attributed to the significant decrease in unmarketable as well as increasing marketable sweet pepper fruit yield. The superior effect of silicon on increasing sweet pepper fruit was reported by Abdel-Aziz (2007) who declared that foliar application of the raw silicon and sodium meta silicate at a rate of $1 \mathrm{~g} / \mathrm{L}$ of each other occurred increasing on average fruit set $\%$, fruit weight, early and total yield/ fed. of tomato plants in the early and late summer seasons, similar results were concerning the favorable effect of kaolin and potassium silicate was reported by Kamal (2013) on sweet pepper and Ahmed (2017) on tomato.

With respect to the superior effect of using foliar application of paclobutrazol especially at the lower rate i.e. $50 \mathrm{mg} / \mathrm{L}$ on fruit set \%, fruit weight, yield and its components of sweet pepper fruit over the control, may be due to the increasing on the thickness of the lamina (leaf blade) and palisade tissue and that are of great interest to create more chloroplasts to improve the development of lateral branches with increasing the flower buds. Also, enhanced flowering, fruit set $\%$ and fruiting. In this respect, it was found that spraying sweet pepper plants with by paclobutrazol lead to decreasing un-marketable yield; this may be attributed to the effects of paclobutrazol as foliage application of plant latex which makes it unpalatable for insects. The current results concerning foliar application of paclobutrazol on the previous aspects are confirmed by Yadava (2012) who decided that foliar application of paclobutrazol at a rate of $50 \mathrm{ppm} / \mathrm{L}$ led to significant increases on flowering, fruit maturity, fruit weight and recorded the highest percentage of fruit set of cape gooseberry plant.

\section{III-Fruit quality characteristics of sweet pepper fruit:}

The data in Table 6 showed that foliar application by various rates of some silicon sources and paclobutrazol treatments under heat stress condition, gave significant differences in all fruit quality parameters i.e. fruit length $(\mathrm{cm})$, fruit diameter $(\mathrm{cm})$, fruit dry weight (\%), total soluble solids (\%), total sugars (\%), total acidity (\%) and ascorbic acid ( $\mathrm{mg} / 100 \mathrm{~g}$ fresh weight) except for spraying the raw silicon on the fruit length in the $1^{\text {st }}$ season, ascorbic acid contains in the $2^{\text {nd }}$ season only, also spraying paclobutrazol at $100 \mathrm{mg} / \mathrm{L}$ on total sugars (\%) in the two late summer seasons respectively, and ascorbic acid contains in the $2^{\text {nd }}$ season only compared to the control 
588 EFFECT OF FOLIAR SPRAY WITH SOME SILICON SOURCES AND PACLOBUTRAZOL ON GROWTH, YIELD AND FRUIT QUALITY OF SWEET PEPPER (CAPSICUM ANNUUM L.) PLANTS UNDER HIGH TEMPERATURE CONDITIONS

treatment. The highest values of fruit quality parameters occurred when sweet pepper plants were sprayed with kaolin followed by potassium silicate. The above results are in agreement with Abdel-Aziz (2007) who advocated that foliar application of the raw silicon and sodium meta silicate led to increase tomato fruit quality in the early and late summer seasons. Kamal (2013) defined that foliar spraying with kaolin and potassium silicate induced an increasing in total sugars and total soluble solids (\%) of sweet pepper fruits.

It is worthwhile to mention here that, potassium silicate is considered as significant supplements of potassium. In this connection, potassium is a key nutrient for enhancing photosynthesis, enzyme activation, cell turgor maintenance, an important role in water status of plant, promoting the synthesis of sugars and polysaccharides. Potassium is involved in numerous biochemical and physiological processes in plants like stomatal regulation for plants depend upon potassium to regulate the opening and closing of stomats. Potassium plays the most important role in fruit quality and flavor, the amount of ascorbic acid in tomato fruit also depends upon potassium nutrition (Irfan, 2015).

Concerning the favorite foliar application of paclobutrazol treatment especially at the lowest rate i.e. $50 \mathrm{ppm} / \mathrm{L}$ on fruit quality parameters, may be attributed to reducing in vegetative growth and the increased partitioning of photosynthetic into fruit and perhaps other plant organs such as roots. Similar findings were also reported

Table 6. Effect of foliar spray with some silicon sources and paclobutrazol treatments on fruit length, fruit diameter, fruit dry weight, total soluble solids, total sugars, total acidity and ascorbic acid content in sweet pepper fruits during the two late summer seasons of 2016 and 2017

\begin{tabular}{|c|c|c|c|c|c|c|c|}
\hline \multirow[b]{2}{*}{ Foliar spray treatments } & Fruit & Fruit & Fruit & Total & Total & Total & Ascorbic \\
\hline & \multicolumn{7}{|c|}{2016} \\
\hline Sodium meta silicate ${ }^{\circledR}$ & 6.76 & 5.75 & 6.60 & 4.51 & 6.28 & 0.45 & 108.60 \\
\hline Potassium silicate $^{\circledR}$ & 8.43 & 7.70 & 7.33 & 4.93 & 6.57 & 0.41 & 123.69 \\
\hline $\mathrm{Kaolin}^{\circledR}$ at $20 \mathrm{~g} / \mathrm{L}$ & 8.84 & 7.93 & 7.69 & 5.13 & 6.74 & 0.34 & 128.82 \\
\hline Raw silicon at $1 \mathrm{~g} / \mathrm{L}$ & 6.23 & 5.45 & 6.35 & 4.45 & 6.18 & 0.32 & 105.23 \\
\hline Sunless ${ }^{\circledR}$ at $2 \mathrm{~cm}^{3} / \mathrm{L}$ & 7.40 & 6.77 & 6.72 & 4.51 & 6.42 & 0.35 & 114.16 \\
\hline Paclobutrazol ${ }^{\circledR}$ at 50 & 7.90 & 7.01 & 6.83 & 4.73 & 6.39 & 0.33 & 118.43 \\
\hline Paclobutrazol ${ }^{\circledR}$ at 100 & 6.56 & 6.00 & 6.23 & 4.49 & 5.32 & 0.32 & 100.44 \\
\hline Control (Tap water) & 5.97 & 4.84 & 5.34 & 3.92 & 4.98 & 0.56 & 88.53 \\
\hline L S D at $5 \%$ & 0.47 & 0.37 & 0.43 & 0.39 & 0.42 & 0.041 & 11.153 \\
\hline Foliar spray treatments & \multicolumn{7}{|c|}{2017} \\
\hline Sodium meta silicate ${ }^{\circledR}$ & 7.16 & 5.52 & 6.27 & 4.42 & 6.01 & 0.49 & 109.23 \\
\hline Potassium silicate ${ }^{\circledR}$ at & 8.44 & 7.42 & 7.48 & 4.88 & 6.23 & 0.32 & 119.44 \\
\hline Kaolin $^{\circledR}$ at $20 \mathrm{~g} / \mathrm{L}$ & 8.86 & 7.76 & 7.76 & 5.09 & 6.64 & 0.29 & 124.35 \\
\hline Raw silicon at $1 \mathrm{~g} / \mathrm{L}$ & 6.29 & 5.30 & 6.11 & 4.35 & 5.84 & 0.40 & 104.94 \\
\hline Sunless ${ }^{\circledR}$ at $2 \mathrm{~cm}^{3} / \mathrm{L}$ & 7.30 & 6.34 & 6.37 & 4.50 & 6.11 & 0.37 & 110.87 \\
\hline Paclobutrazol ${ }^{\circledR}$ at 50 & 7.89 & 6.91 & 6.43 & 4.72 & 6.11 & 0.36 & 116.65 \\
\hline Paclobutrazol $^{\circledR}$ at 100 & 6.43 & 5.87 & 5.91 & 4.36 & 5.22 & 0.50 & 103.26 \\
\hline Control (Tap water) & 5.82 & 4.82 & 5.09 & 3.52 & 4.97 & 0.57 & 96.42 \\
\hline L S D at $5 \%$ & 0.41 & 0.35 & 0.47 & 0.39 & 0.49 & 0.059 & 9.983 \\
\hline
\end{tabular}


by Yadava (2012) who regarded that foliar application of paclobutrazol at a rate of 50 $\mathrm{ppm} / \mathrm{L}$ significantly increased total soluble solids and decreased total acidity (\%) of cape gooseberry fruit.

\section{IV- Chemical composition of sweet pepper leaves:}

The data presented in Table (7) clearly demonstrated that there were significant differences in the effect of foliar application of some silicon sources and paclobutrazol treatments under heat stress condition during the two late summer seasons of chemical composition contents of sweet pepper leaves i.e. total chlorophyll (mg/100 g fresh weight), total sugars, proline $(\mathrm{mg} / \mathrm{g})$, nitrogen, phosphorus and potassium (\%) with the exception of spraying sweet pepper plants with the raw silicon on the total chlorophyll in the $1^{\text {st }}$ season only and on proline in the two late summer seasons, sodium meta silicate of proline in the $1^{\text {st }}$ season only and paclobutrazol at the highest rate on potassium content in the two late summer seasons, respectively. The previous findings coincided with Kamal (2013) who reported that spraying kaolin and potassium silicate significantly enhanced total chlorophyll, nitrogen, phosphorus and potassium (\%) uptake of sweet pepper plant in both seasons. With respect to the effect of using foliar application silicon sources, results showed also, higher concentrations of chlorophyll per unit area of leaf tissue.

This means that the plant is able to tolerate higher light levels by using more of the available light as well as silicon deposited in the plant tissues helps to alleviate water stress by decreasing transpiration and improves light interception by keeping the leaf blade erect in position and subsequent increasing photosynthetic pigments activity with an indirect action. Silicon reduced leaching of nitrogen, phosphorous and potassium lead to increases in minerals uptake and improved soil texture.

Table 7. Effect of foliar spray with some silicon sources and paclobutrazol treatments on chemical composition contents in the dry leaves of sweet pepper plants during the two late summer seasons of 2016 and 2017

\begin{tabular}{|c|c|c|c|c|c|c|c|c|c|c|c|c|}
\hline \multirow[t]{2}{*}{$\begin{array}{l}\text { Foliar spray } \\
\text { treatments }\end{array}$} & \multicolumn{2}{|c|}{$\begin{array}{l}\text { Total chlorophyll } \\
\mathrm{mg} / 100 \mathrm{~g} \\
\text { (F. W. })\end{array}$} & \multicolumn{2}{|c|}{$\begin{array}{c}\text { Total sugars } \\
(\mathrm{mg} / \mathrm{g})\end{array}$} & \multicolumn{2}{|c|}{ Proline (mg/g) } & \multicolumn{2}{|c|}{$\begin{array}{l}\text { Nitrogen } \\
(\%)\end{array}$} & \multicolumn{2}{|c|}{$\begin{array}{c}\text { Phosphorus } \\
(\%)\end{array}$} & \multicolumn{2}{|c|}{$\begin{array}{l}\text { Potassium } \\
(\%)\end{array}$} \\
\hline & 2016 & 2017 & 2016 & 2017 & 2016 & 2017 & 2016 & 2017 & 2016 & 2017 & 2016 & 2017 \\
\hline $\begin{array}{c}\text { Sodium meta } \\
\text { silicate }^{\otimes} \text { at } 1 \mathrm{~g} / \mathrm{L}\end{array}$ & 162.96 & 161.70 & 25.70 & 24.20 & 0.27 & 0.31 & 3.58 & 3.56 & 0.497 & 0.44 & 3.88 & 3.77 \\
\hline $\begin{array}{c}\text { Potassium silicate }^{\mathbb{\theta}} \\
\text { at } 1 \mathrm{~g} / \mathrm{L}\end{array}$ & 172.75 & 171.60 & 31.13 & 29.47 & 0.40 & 0.41 & 3.80 & 3.79 & 0.57 & 0.54 & 4.76 & 5.05 \\
\hline Kaolin $^{\oplus}$ at $20 \mathrm{~g} / \mathrm{L}$ & 180.96 & 180.48 & 33.00 & 32.37 & 0.43 & 0.44 & 3.96 & 4.03 & 0.63 & 0.63 & 4.39 & 4.56 \\
\hline Raw silicon at $1 \mathrm{~g} / \mathrm{L}$ & 158.80 & 159.76 & 23.30 & 22.10 & 0.26 & 0.28 & 3.62 & 3.62 & 0.53 & 0.49 & 3.82 & 3.69 \\
\hline $\begin{array}{c}\text { Sunless }^{\circledR} \text { at } 2 \mathrm{~cm}^{3} / \\
L\end{array}$ & 166.35 & 164.84 & 28.37 & 25.37 & 0.36 & 0.38 & 3.72 & 3.73 & 0.55 & 0.51 & 4.13 & 3.94 \\
\hline $\begin{array}{c}\text { Paclobutrazol }^{\mathbb{8}} \text { at } \\
50 \mathrm{mg} / \mathrm{L}\end{array}$ & 168.76 & 167.23 & 28.00 & 27.03 & 0.33 & 0.36 & 3.68 & 3.68 & 0.50 & 0.51 & 4.03 & 3.83 \\
\hline $\begin{array}{c}\text { Paclobutrazo }\left.\right|^{\mathbb{B}} \text { at } \\
100 \mathrm{mg} / \mathrm{L}\end{array}$ & 160.58 & 157.81 & 25.33 & 24.33 & 0.30 & 0.34 & 3.51 & 3.52 & 0.44 & 0.43 & 3.72 & 3.58 \\
\hline Control (Tap water) & 150.18 & 149.78 & 19.80 & 19.70 & 0.24 & 0.26 & 3.33 & 3.10 & 0.350 & 0.370 & 3.55 & 3.43 \\
\hline LSD at $5 \%$ & 8.840 & 7.256 & 3.127 & 2.404 & 0.051 & 0.038 & 0.093 & 0.189 & 0.051 & 0.060 & 0.271 & 0.194 \\
\hline
\end{tabular}


590 EFFECT OF FOLIAR SPRAY WITH SOME SILICON SOURCES AND PACLOBUTRAZOL ON GROWTH, YIELD AND FRUIT QUALITY OF SWEET PEPPER (CAPSICUM ANNUUM L.) PLANTS UNDER HIGH TEMPERATURE CONDITIONS

The favorable effect of paclobutrazol for increase chlorophyll content prevents chlorophyll degradation and delayed senescence. Chlorophyll content is one of the main factors stimulating the rate of photosynthesis and biological productivity may be ascribed to higher cytokinin content that is known to stimulate chlorophyll biosynthesis and reduced chlorophyll catabolism and delayed senescence. Paclobutrazol mode of action is reported by holding up energy transport to the mitochondria and preventing the biosynthesis gibberellin thus, cell elongation will reduce accompanied with shortened above ground bone, while contributing to the enhancement of photosynthesis and minerals uptake. Similar results concerning the simulative effect of paclobutrazol treatment on the chemical compositions content of sweet pepper leaves were found by Atilla (2014) who indicated that treating tomato plants with paclobutrazol at the rate of $40 \mathrm{mg} / \mathrm{L}$ as a foliar application increased the total chlorophyll which induce enhancement of photosynthesis activity, proline, soluble sugars and stimulation minerals uptake processes.

\section{V-Economic evaluation:}

Data registered in Table 8 indicated that the total income of either the foliar spray treatments from silicon sources and paclobutrazol or the control treatment (spray with tap water). It is obvious from the Table 8 that, spraying pepper plants by different silicon sources or paclobutrazol achieved the highest gross return and net returns, but the preferable treatments were from kaolin which was (13.065 E. P.), then from

Table 8. Effect of foliar spray with some silicon sources and paclobutrazol treatments on net income/ fed. on average total yield (ton/ fed.) of sweet pepper fruit during the two late summer seasons of 2016 and 2017

\begin{tabular}{|c|c|c|c|c|c|c|}
\hline & Average of & Total income & Costs of the & Net income & Net return & $\mathrm{Ra}$ \\
\hline Sodium meta & 9.498 & 33.243 & 425.0 & 32.818 & 6.327 & 5 \\
\hline Potassium & 10.947 & 38.315 & 498.0 & 37.817 & 11.326 & $\underline{2}$ \\
\hline Kaolin $^{\circledR}$ at $20 \mathrm{~g} / \mathrm{L}$ & 11.483 & 40.191 & 625.0 & 39.566 & 13.065 & 1 \\
\hline Raw silicon at & 8.548 & 29.918 & 415.0 & 29.503 & 3.012 & 6 \\
\hline Sunless ${ }^{\circledR}$ at & 10.117 & 35.410 & 606.0 & 34.804 & 8.313 & 4 \\
\hline Paclobutrazol $^{\circledR}$ at & 10.340 & 36.190 & 505.0 & 35.685 & 9.194 & 3 \\
\hline Paclobutrazol ${ }^{\circledR}$ at & 8.237 & 28.830 & 610.0 & 28.220 & 1.729 & 7 \\
\hline Control & 7.683 & 26.891 & 400.0 & 26.491 & 0.0 & 8 \\
\hline
\end{tabular}

potassium silicate which was (11.326 E. P.) and paclobutrazol (9.194 E. P.) for fed., respectively while, the lowest value of gross return and net return were obtained from the control treatment.

*Average selling price of one ton from sweet pepper fruits during the growth season $=3.500$ L.E. / fed.

$*$ Purchase price of one kilogram of sodium meta silicate $=25.00$ L.E.

$*$ Purchase price of one kilogram of potassium silicate $=65.00$ L.E. 
$*$ Purchase price of one kilogram of kaolin clay $=7.50$ L.E.

$*$ One kilogram of the fine crushed of the raw silicon $=15.00$ L.E.

$*$ Purchase price of one package of sunless $\left(800 \mathrm{~cm}^{3}\right)=55.00$ L.E.

*Purchase price of one package of paclobutrazol $(125 \mathrm{~g})=175.00 \mathrm{~L}$.E.

${ }^{*}$ Cost of the agricultural worker for spraying each treatment $=100$ L.E.

\section{CONCLUSION}

According to the previous results, it could be concluded that, spraying the plants under the late summer season, with any one of silicon sources as kaolin or potassium silicate or using paclobutrazol compound at rate of $50 \mathrm{mg} / \mathrm{L}$, respectively is very important, the preferable one was kaolin which applied after 30 days from transplanting and repeated at 15 day intervals at four times to protect the pepper plants from the high temperature injury during the summer season and led to obtain vigour growth, highest fruit yield with the best quality and highest net return.

\section{REFERENCES}

1. Abdel-Aziz, M. A. 2007. Some physiological studies on tomato plant. Ph. D. Thesis, Fac. Agric., Cairo Univ., Egypt.

2. Ahmed, A. 2017. Impacts of kaolin and Pinoline foliar application on growth, yield and water use efficiency of tomato (Solanum lycopersicum L.) grown under water deficit. J. Saudi Soc. Agric. Sci., http://dx.doi.org/10.1016/j. jssas.08.001, 1-13.

3. A.O.A.C. 2005. Official Methods of Analysis. $18^{\text {th }}$ Ed. Association of official agricultural chemists, Washington, DC, USA.

4. Atilla, L. T. 2014. Influence of foliarly applied different triazole compounds on growth, nutrition and antioxidant enzyme activities in tomato (Solanum lycopersicum L.) under salt stress. Australian J. Crop Sci., 8(1):71-79.

5. Blanco-Ríos, A. K.; L. A. Medina-Juarez; G. A. González-Aguilar and N. GamezMeza. 2013. Antioxidant activity of the phenolic and oily fractions of different sweet bell peppers. J. Mex. Chem. Soc., 57, 137-143.

6. Bremner, J. M. and C. S. Mulvaney. 1982. Total nitrogen. In: Pag, A. L., R. H. Miller and D. R. Keeny (Ed.). Methods of Soil Analysis. Part 2, Amer. Soc. Agron. Madison, W. I. USA, 595-624.

7. Bricker, B. 1991. MSTATC: A micro computer program from the design management and analysis of agronomic research experiments. Michigan State Univ. USA. 
592 EFFECT OF FOLIAR SPRAY WITH SOME SILICON SOURCES AND PACLOBUTRAZOL ON GROWTH, YIELD AND FRUIT QUALITY OF SWEET PEPPER (CAPSICUM ANNUUM L.) PLANTS UNDER HIGH TEMPERATURE CONDITIONS

8. Dubois, M.; K. M. Gilles; J. K. Hamilton; P. A. Robers and F. Smith. 1975. Calorimetric method for determination of sugars and related substances. Analyst., Chem. 28:350.

9. Horneck, D. A. and D. Hanson. 1998. Determination of potassium and sodium by Flam Emission Spectrophotometry. In Handbook of Referance Methods for plant analysis. Kalra, Y. P. (Ed.):153-155.

10. Irfan, A. B. H.; M. A. B. Basra; S. H. Ullah; S. Qamar and K. Muhammad. 2015. Foliar application of potassium improves fruit quality and yield of tomato plants. Acta Sci. Pol., Hortorum Cultus, 14 (1): 3-13.

11. Jackson, M. L. 1973. Soil Chemical Analysis. Prentic-Hall, Indian.

12. Kamal, A. M. 2013. Influence of irrigation levels, antitranspirants and potassium silicate on growth, fruit yield and quality of sweet pepper plants (Capsicum annuum L.) grown under drip irrigation. J. Plant Production, Mansoura Univ., 4 (11): $1581-1597$.

13. Nagata, M. and I. Yamashita. 1992. Simple method for simultaneous determination of chlorophyll and carotenoids in tomato fruit. J. Japan Soc. Food Sci., Technol. 39: 928-932.

14. Olsen, S. R. and L. E. Sommers. 1982. Phosphorus. In: Page, R. H. Miller and D. R. Keeney (Ed.). Methods of Soil Analysis. Part 2 Amer. Soc. Agron. Madison, W. I. USA: 403-430.

15. Piper, G. S. 1947. Soil and Plant Analysis. Interscience Publishers, Inc. NY, 368.

16. Tran, L. T. and K. Murakami. 2015. Effect of high temperature on fruit productivity and seed-set of sweet pepper (Capsicum annuum L.) in the field condition. J. Agric. Sci. Technology A and B and Hue Univ. J. Sci., 5: 515-520.

17. Troll, W. and J. Lindsley. 1955. A photometric method for determination of proline. J. Biol., Chem., 215:655-660.

18. Unyayar, S. and C. F. Ozlem. 2005. Changes in antioxidative enzymes of young and mature leaves of tomato seedlings under drought stress. Turk Biol., 29: 211-216.

19. Yadava, L. P. 2012. Effect of growth retardants on floral biology, fruit set and fruit quality of Cape gooseberry (Physalis peruviana L.). Amer. J. Plant Physio., 7: 143-148. 


\section{تأثير الرش بيعض مصادر السيليكون والباكلوبيوترازول على النمو و المحصول وجودة الثمار فى نباتات الفلقل الحول تحت ظروف الحرارة المرتفعة}

\section{مدحت أحمد عبد العزيز ، ربيع حسن محمد غيث}

قسم بحوث الخضر ذاتية الثلقيح، معهُ بحوث البساتين- مركز البحوث الزراعية- الجيزة- مصر

أجريت هذه التجربة بمحطة بحوث سدس - مركز البحوث الزر اعية - محافظة بنى ســويف

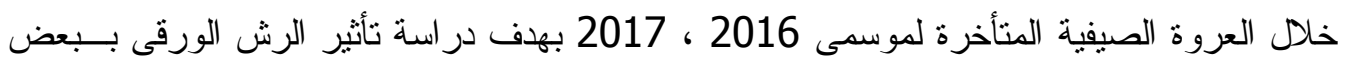

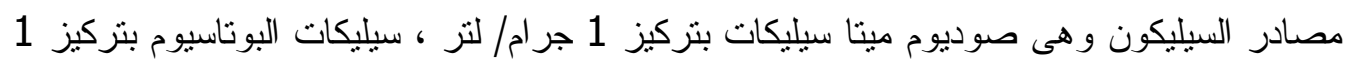

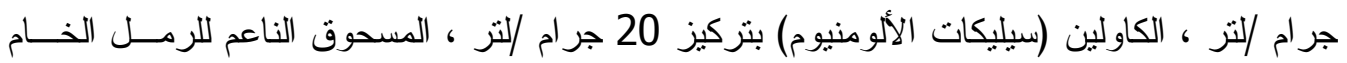

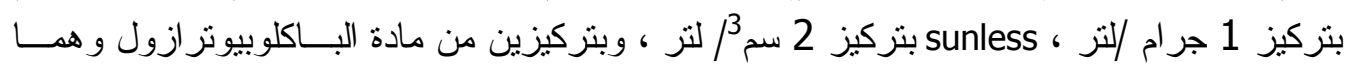

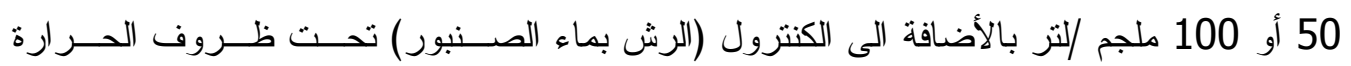

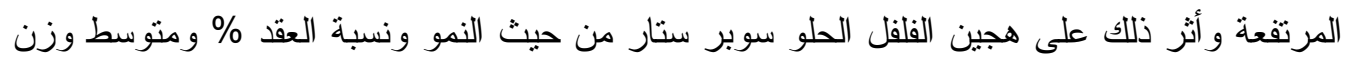

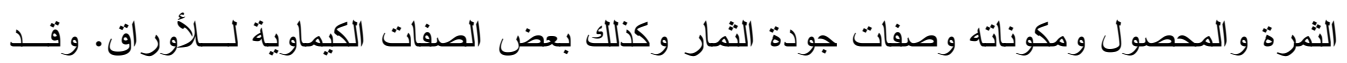

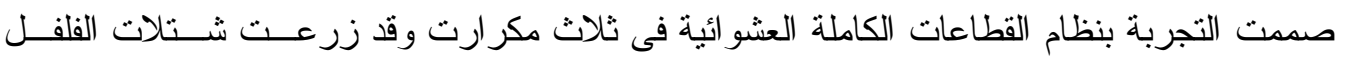

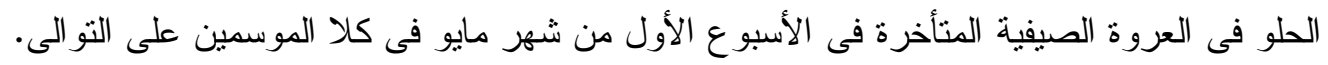

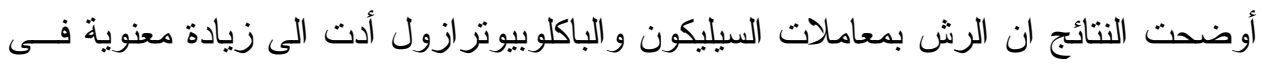

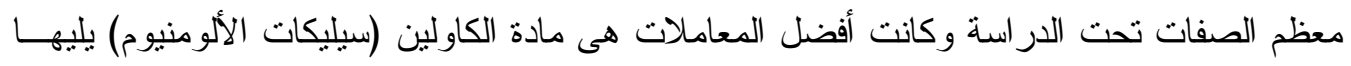

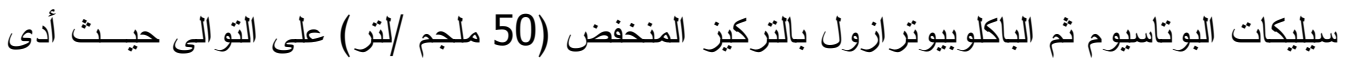

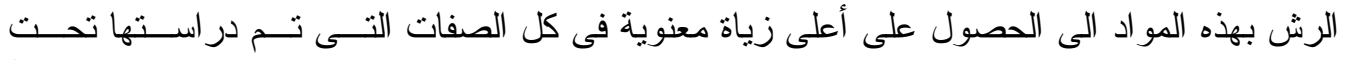

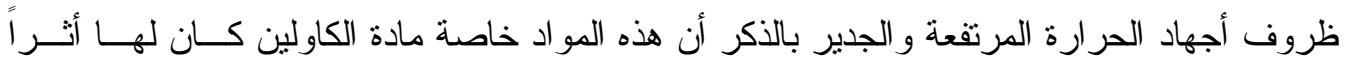

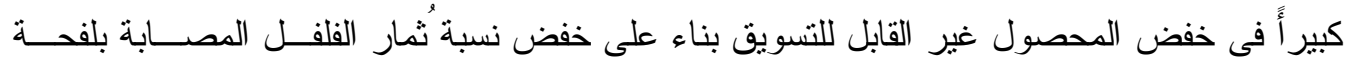

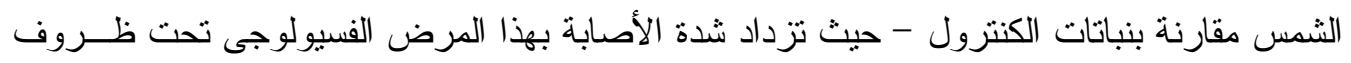

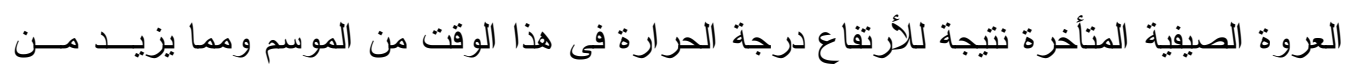

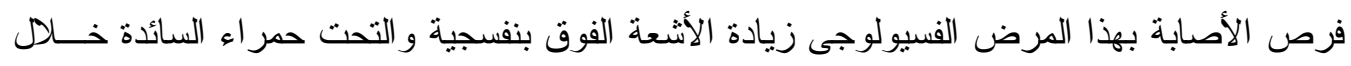

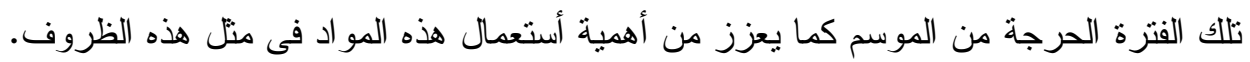

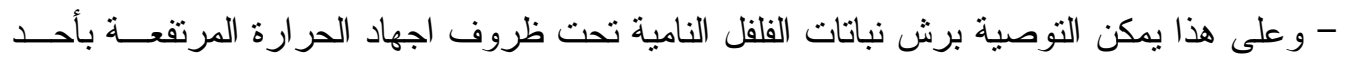

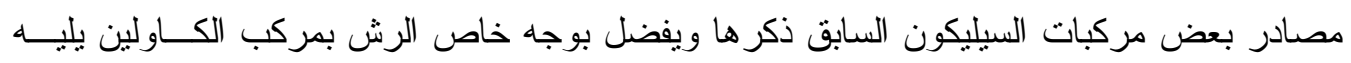

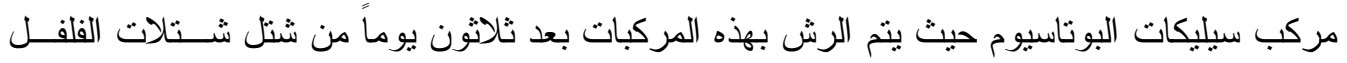

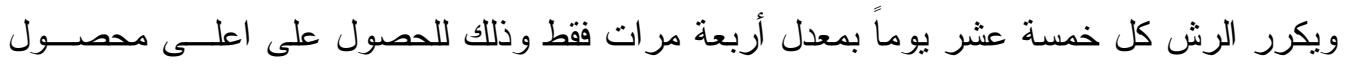

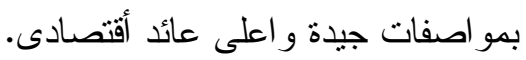
الكلمات الداله: الفلفل الحلو - أجهاد الحرارة المرتفعة - الكاولين - السيليكون - الباكلوبيوترازول 
